\title{
Indhold 2014
}

\section{Artikler}

Aas, Geir; Voldsudsatte kvinner og deres erfaringer med politiet

Garde, Peter; Omskærelse, forbrydelse eller gudsdyrkelse - Foredrag i

Rødovre Præstekonvent

Giertsen, Hedda og Marte Rua: Møtested for Straff og Velferd. Rusme-

stringsavdelinger i fengsel, ansattes syn

Giertsen, Hedda og Torsten Kolind: Fengslenes innsats overfor innsatte med rusproblemer: ansattes perspektiv

Holm, Claes, Odd Lindberg, Elma Jukic og Per-Åke Nylander: Flera nyan-

ser av blått. Kriminalvårdare på behandlingsavdelingar - deras be-

skrivningar av yrkesroller, drogbehandling och de intagna

Huitfeldt, Iver: Strafferettsreform i Moldova - En studie i rettsendring 234

Johansen, Nicolay B.; Kriminalitetens eksistens - kategorisk form og stoff .

Kolind, Torsten, Vibeke Asmussen Frank og Karina Holm: Stofbehandling og nye institutionelle identiteter i danske fængsler

Mathiasen, Peter Dueholm; Virtuelle ting - Kan virtuelle ting strafferetligt karakteriseres eller sidestilles som rørlige ting?

Minke, Linda Kjør og Rikke Gottrup: »Med et fingerknips« - overførsler af indsatte mellem danske fængsler

Olesen, Annette: Retlige, sikkerhedsmæssige og resocialiserende omkostninger ved sagsomkostninger i

straffesager

Tourunen, Jouni og Teemu Kaskela: »Give them a chance« - The social representation of the counsellor's institutional role in prison-based drug treatment programmes in Finland

\section{Boganmeldelser}

Aarli, Ragna af Vibeke Borberg: Offentlig rettergang. Publikums adgang

til innsyn i og omtale av straffesaker 316

Asp, Petter af Morten Holmboe: Sex och Samtycke

Cameron, Ian, Malin Thunberg Schunke, Karin Pale-Bartes, Christoffer

Wong og Petter Asp af Henning Bang Fuglsang Madsen Sørensen: International Criminal Law from a Swedish Perspective 
Fransen, Peter af Peter Garde: Borgen med de mange ansigter. Statsfængslet i Nyborg 1913-2013

Greve, Vagn af Claes Lernestedt: Træk af kolonistrafferetten i komparativ belysning

Høgberg, Alf Petter, Trond Eirik Schea og Runar Torgersen af Peter Garde: Retssikker radikaler. Festskrift til Ståle Eskeland 70 år

Kury, Helmut og Evelyn Shea af Linda Grøning: Punitivity: International

Developments

Lien, Inger-Lise af Anette Storgaard: I bakvendtland - kriminelle liv 282

Minke, Linda Kjoer af Morten Højgaard: Fængslets indre liv 302

Suominen, Annika af Petter Asp: The Principle of Mutual Recognition in

Cooperation in Criminal Matters. A study of the principle in four framework decisions and in the implementation legislation in the Nordic Member State

Szarek-Mason, Patrycja af Lars Bo Langsted: The European Union's Fight Against Corruption

Westfelt, Lisa af Annika Elisabet Suominen: Migration som straff? Utvisning på grund av brott 1973-2003 med fokus på flyktningskydd

\section{Debat}

Garde, Peter: Replik til Sturla Stålsett 276

Olaussen, Leif Petter: Kriminalitetens eksistens - fortegnet opprydding 205 Stålsett, Sturla J.: Rituell omskjæring av guttebarn - et etisk og juridisk dilemma. Kommentar til Peter Gardes artikkel »Omskærelse, forbrydelse eller gudsdyrkelse« 271

Wandall, Rasmus H.: Rule of Law, retsændringer og retskultur

\section{Diverse}

Indhold 2013 